\title{
Analisis Potensi Penerimaan Retribusi Daerah Pada Pemerintah Kabupaten Gorontalo
}

\author{
RAHMA DEWI LIPUTO ${ }^{1}$, JULLIE J. SONDAKH ${ }^{2}$, JESSY D.L WARONGAN ${ }^{3}$ \\ ${ }^{1,2,3}$ Program Magister Akuntansi, Fakultas Ekonomi dan Bisnis Universitas Sam Ratulangi \\ email: dewigode7384@gmail.com ${ }^{1}$,julliesondakh@yahoo.com ${ }^{2}$,jdimarcus@gmail.com ${ }^{3}$
}

\begin{abstract}
This study aims to determine and analyze the potential of local retribution revenue, the constraints of local retribution and efforts to overcome those constraints of local retribution revenue in Gorontalo Regency. This is a qualitative research and case study approach. Data were obtained through in-depth interviews, documentation study and observation. The results showed that the potential of each type of retribution in Gorontalo Regency is classified as follows: 1) Local retributions belong to the prime classification are the retributions on the use of regional property, building permits and noise permits; 2) Potential local retributions are from health service, market service, wholesaler/retailer, terminals and recreation areas and sports;3) Developing local retributions are classified as from motor vehicle and telecommunication towers; 4) underdeveloped retributions are from collected garbage, public roadside parking, special parking area, abattoir, local product sales and route permit. The constraints in gaining those retribution revenues are: 1)inadequate of human resources in terms of quantity and quality; 2) inadequate facilities; 3) lack of supervision; 4) insufficient of sanctions; 5) lack of taxpayer awareness; 6) lack of socialization and 7) lack of coordination. The efforts made to overcome those constraints are by: 1) intensifying the implementation of regional retribution intensification; 2) intensifying regional retribution extensification and 3)Local Government needs to provide incentive rewards to regional work units for their well achievements.
\end{abstract}

Keywords: Local Retribution and Local Revenue

\begin{abstract}
Abstrak. Penelitian ini bertujuan untuk mengetahui dan menganalisis potensi penerimaan retribusi daerah, kendala-kendala penerimaan retribusi daerah dan upaya-upaya untuk mengatasi kendala-kendala penerimaan retribusi daerah di Kabupaten Gorontalo. Metode penelitian menggunakan jenis kualitatif dengan pendekatan studi kasus. Data diperoleh melalui teknik wawancara yang mendalam, studi dokumentasi dan observasi. Hasil penelitian menunjukan bahwa potensi penerimaan retribusi di Kabupaten Gorontalo diklasifikasikan sebagai berikut:1) Retribusi daerah yang tergolong klasifikasi prima adalah adalah retribusi pemakaian kekayaan daerah, retribusi izin mendirikan bangunan dan retribusi izin gangguan/keramaian; 2) Retribusi daerah yang tergolong potensial adalah retribusi pelayanan kesehatan, retribusi pelayanan pasar, retribusi pasar grosir/pertokoan, retribusi terminal dan retribusi tempat rekreasi dan olahraga; 3) Retribusi daerah yang tergolong berkembang adalah retribusi pengujian kendaraan bermotor dan retribusi menara telekomunikasi; 4) Retribusi daerah yang tergolong terbelakang adalah retribusi persampahan/kebersihan, retribusi parkir tepi jalan umum, retribusi tempat parkir khusus, retribusi rumah potong hewan, retribusi penjualan produk usaha daerah dan retribusi izin trayek. Kendala-kendala penerimaan retribusi di Kabupaten Gorontalo adalah: 1) Sumber Daya Manusia secara kuantitas dan kualitas belum memadai; 2) Fasilitas yang kurang memadai; 3) Kurangnya pengawasan; 4) Penerapan sanksi yang belum maksimal; 5) Kurangnya kesadaran wajib retribusi; 6) Kurangnya sosialisasi dan 7) Kurangnya koordinasi. Upaya-upaya yang dilakukan untuk mengatasi kendala-kendala penerimaan retribusi daerah di Kabupaten Gorontalo yaitu: 1) Menggiatkan pelaksanaan intensifikasi retribusi daerah; 2) Menggiatkan pelaksanaan ekstensifikasi retribusi daerah dan 3) Pemerintah Kabupaten Gorontalo memberikan insentif kepada SKPD yang melaksanakan pemungutan retribusi daerah atas pencapaian kinerja tertentu.
\end{abstract}

Kata kunci: Retribusi Daerah dan Pendapatan Asli Daerah

\section{Pendahuluan}

Berlakunya Undang-Undang Nomor 28 tahun 2009 tentang Pajak Daerah dan Retribusi Daerah, memberikan kewenangan yang besar kepada daerah dalam upaya peningkatan penerimaan PAD yang bertujuan untuk meningkatkan akuntabilitas daerah dalam penyediaan pelayanan. Kualitas pelayanan publik diharapkan bisa lebih baik dengan adanya peningkatan Pendapatan Asli Daerah yang bersumber dari penerimaan retribusi daerah, karena retribusi daerah berkontribusi langsung terhadap penyediaan layanan publik oleh pemerintah daerah.

Pemungutan retribusi berhubungan dengan masyarakat pengguna layanan publik (Public service), peningkatan retribusi secara otomatis akan mendorong peningkatan kualitas pelayanan publik, dengan demikian pemerintah daerah ditantang untuk meningkatkan kinerjanya dalam memberikan pelayanan kepada publik. Pemungutan retribusi daerah di Kabupaten Gorontalo 
dilakukan berdasarkan Undang-Undang Nomor 28 Tahun 2009 tentang Pajak daerah dan retribusi daerah serta Peraturan Daerah Nomor 1 Tahun 2012 tentang retribusi jasa umum, Peraturan Daerah Nomor 2 tentang retribusi jasa usaha dan Peraturan Nomor 3 Tahun 2012 tentang retribusi perizinan tertentu. Presentase realisasi penerimaan ketiga jenis retribusi tersebut setiap tahunnya mengalami fluktuatif, hal tersebut menggambarkan bahwa penetapan target penerimaan retribusi di Kabupaten Gorontalo belum dilaksanakan sesuai dengan penilaian potensi riilnya.

Berdasarkan data yang ada, target dan capaian penerimaan retribusi daerah Kabupaten Gorontalo tahun 2011, realisasinya hanya 83,87\%, tahun 2012 targetnya meningkat dan realisasi capaiannya sebesar 93,40\%, sedangkan tahun 2013 penetapan target diturunkan dari tahun sebelumnya dan capaian realisasinya sebesar $124,45 \%$, walaupun tahun sebelumnya capaiannya sudah melampaui target yang ditetapkan tetapi untuk tahun 2014 target penerimaan retribusi malah diturunkan dan capaian realisasinya sebesar 120,05\%. Selanjutnya tahun 2015 target ditetapkan lebih tinggi dari tahun sebelumnya akan tetapi realisasinya malah turun hanya sebesar 84,14\%. Tahun 2016 target retribusi kembali diturunkan dan realisasi yang dicapai melampaui target yakni 115,79\%.

Penurunan target penerimaan retribusi di Kabupaten Gorontalo disebabkan karena dengan terbitnya UU No. 28 tahun 2009 tentang Pajak Daerah dan retribusi Daerah mengakibatkan ada beberapa jenis retribusi tidak dipungut lagi. Selain itu 2 (dua) jenis retribusi yang sudah tidak tidak dipungut lagi di Kabupaten Gorontalo, walaupun dalam UU No. 28 tahun 2009 masih dimungkinkan untuk dipungut yaitu retribusi penggantian KTP dan Akta Kelahiran Catatan Sipil dan retribusi izin usaha perikanan.

Selain itu teridentifikasi pula bahwa penetapan target penerimaan retribusi di Kabupaten Gorontalo belum didasarkan potensi penerimaannya, ini dapat dilihat dari kontribusi penerimaan retribusi terhadap PAD yang semakin menurun setiap tahunnya. Hal ini menggambarkan bahwa SKPD pengelola retribusi daerah belum optimal dalam meningkatkan penerimaan retribusi daerah yang dikelolanya. Rendahnya kontribusi penerimaan retribusi terhadap PAD tentu saja mempengaruhi tingkat kemandirian keuangan Pemerintah Kabupaten Gorontalo, karena belum menggali potensi penerimaan dari sumber-sumber penerimaan yang ada di daerah, sehingga masih sangat bergantung pada dana dari pusat.

Tujuan penelitian ini adalah untuk menganalisis potensi penerimaan retribusi daerah dan kendala-kendala penerimaan retribusi daerah serta upaya-upaya untuk mengatasi kendala-kendala penerimaan retribusi daerah di Kabupaten Gorontalo.

\section{Model Analisis}

Model analisis dalam penelitian ini diawali dengan melihat fenomena yang terjadi dalam pengelolaan retribusi daerah di Kabupaten Gorontalo terkait dengan fokus penelitian yaitu tentang pengambilan keputusan dalam penetapan target penerimaan retribusi daerah. Selanjutnya melakukan pengumpulan data dengan melakukan wawancara yang didukung oleh studi dokumentasi, rekaman arsip dan observasi langsung. Tahapan selanjutnya yaitu mengolah data dengan menggunakan tahapan yang dikemukakan oleh Miles dan Huberman dalam Afrizal (2016:180) yaitu reduksi data, kategorisasi dan penarikan kesimpulan, kemudian dilakukan pengujian keabsahan data dan tahapan terakhir yakni membuat laporan hasil penelitian.

Gambar 1 : Model Analisis

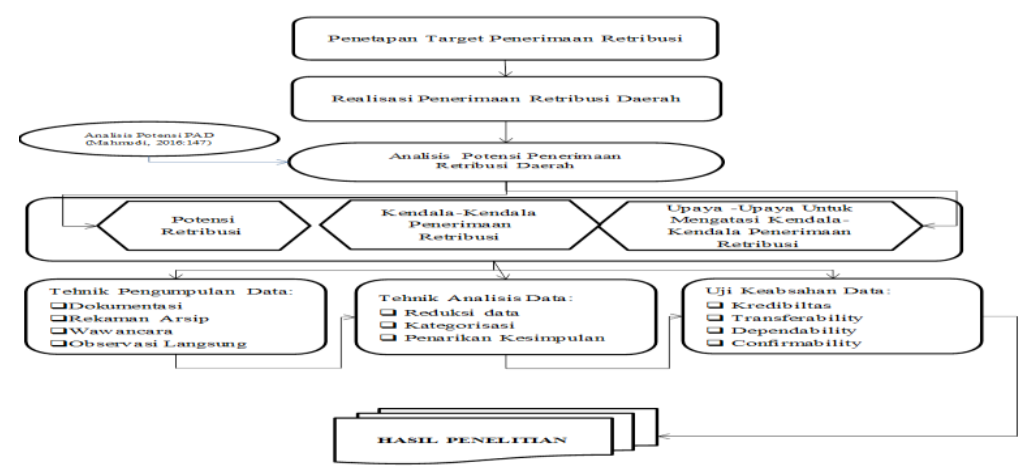

\section{Metode Penelitian}

Penelitian ini menggunakan metode kualitatif, metode penelitian kualitatif menurut Sugiyono (2015:1) sering disebut metode penelitian naturalistik karena penelitiannya dilakukan pada kondisi 
yang alamiah (natural setting). Obyek yang alamiah atau natural setting adalah obyek yang apa adanya, tidak dimanipulasi oleh peneliti sehingga kondisi pada saat peneliti memasuki obyek, setelah berada di obyek dan setelah keluar dari obyek relatif tidak berubah (Sugiyono, 2015:2). Jenis penelitian yang digunakan pada penelitian ini adalah jenis penelitian kualitatif dengan pendekatan studi kasus. Pendekatan studi kasus dalam penelitian ini terkait dengan fenomena yang terjadi yaitu penetapan target masih fluktuatif dan belum berdasarkan potensi riil penerimaan retribusi daerah yang merupakan kejadian yang berulang sejak tahun 2011 sampai dengan tahun 2016. Hal ini terkait pula dengan fokus penelitian yang tertuang dalam pertanyaan riset yaitu bagaimana potensi penerimaan retribusi daerah di Kabupaten Gorontalo dan apa kendala-kendala dalam penerimaan retribusi daerah serta apa upaya-upaya untuk mengatasi kendala dalam penerimaan retribusi daerah di Kabupaten Gorontalo.

Sumber data yang digunakan dalam penelitian ini adalah data primer yang didapat dari hasil wawancara yang mendalam dengan beberapa informan dan data sekunder berupa data target dan realisasi retribusi daerah Kabupaten Gorontalo tahun 2011 sampai dengan 2016. Tehnik pengumpulan data dalam penelitian ini adalah dokumentasi, rekaman arsip, wawancara dan observasi langsung. Dalam Penelitian ini jumlah informan adalah 19 (sembilanbelas) orang. Kriteria pemilihan informan dalam penelitian ini adalah pihak yang berhubungan dengan pengelolaan retribusi daerah, yaitu Kepala SKPD/Sekretaris/Kepala Bidang/Kepala Seksi di SKPD pengelola retribusi daerah. Semua informan melaksanakan tugas dan fungsi yang berkaitan dengan pemungutan retribusi daerah di Kabupaten Gorontalo.

Dalam penelitian ini proses analisis data menggunakan tahapan yang dikemukakan oleh Miles \& Huberman dalam Afrizal (2016:180) yaitu Reduksi data, kategorisasi dan penarikan kesimpulan. Uji keabsahan data yang digunakan dalam penelitian ini meliputi uji credibility (validitas internal) dengan menggunakan metode triangulasi dalam pengujian kredibilitas, uji transferability (validitas eksternal) yang menunjukkan derajat ketepatan atau dapat diterapkannya hasil penelitian ke populasi dimana sampel tersebut diambil, uji dependability (reliabilitas) dilakukan dengan cara pemeriksaan kembali terhadap keseluruhan proses penelitian. Caranya dilakukan oleh peneliti yang independen atau researcher pembimbing yang telah memiliki pengalaman dan kecakapan yang memadai untuk mengecek keseluruhan aktivitas penelitian, mulai dari menentukan masalah/fokus, memasuki lapangan, menentukan sumber data, melakukan analisis data, melakukan uji keabsahan data sampai pada membuat kesimpulan dan terakhir adalah uji confirmability (objektivitas) berarti menguji hasil penelitian, dikaitkan dengan proses yang dilakukan. Bila hasil penelitian merupakan fungsi dari proses penelitian yang dilakukan, maka penelitian telah memenuhi standar confirmability. Dalam penelitian, jangan sampai proses tidak ada, tetapi hasilnya ada.

\section{Analisis Dan Pembahasan}

Penelitian ini dilakukan selama \pm 3 (tiga) bulan, terhitung mulai bulan Juni sampai dengan Agustus 2017 pada seluruh SKPD pengelola retribusi daerah. Wawancara dilakukan berdasarkan pedoman wawancara yang telah disusun dengan menggunakan alat rekam untuk merekam informasi yang disampaikan dan kamera untuk mendokumentasikan kegiatan dalam proses pengumpulan data serta laptop untuk mengetik hasil penelitian dari rekaman wawancara sehingga berbentuk transkrip wawancara. Hasil dalam penelitian ini untuk menjawab rumusan masalah didapatkan melalui prosedur analisis data yakni melakukan reduksi data untuk menentukan data yang penting dan tidak penting, kemudian dilakukan kategorisasi data untuk memilah-milah hasil wawancara ke dalam bagian yang memiliki kesamaan kemudian dilakukan penarikan kesimpulan. Berdasarkan analisis data hasil wawancara ditemukan 5 (lima) tema berkaitan dengan rumusan masalah pertama, yakni : regulasi, penetapan target, tarif, sistim dan prosedur dan potensi penerimaan. Rumusan masalah kedua dalam penelitian ini yakni, Apa kendala -kendala penerimaan retribusi daerah di Kabupaten Gorontalo, berdasarkan hasil wawancara ditemukan 7 (tujuh) tema utama yang merupakan kendala dalam penerimaan retribusi daerah di Kabupaten Gorontalo, yakni SDM secara kuantitas dan kualitas belum memadai, fasilitas yang belum memadai, kurangnya pengawasan, penerapan sanksi belum maksimal, kurangnya kesadaran wajib retribusi, kurangnya sosialisasi dan kurangnya koordinasi. Rumusan masalah ketiga dalam penelitian ini yakni: Apa upaya -upaya untuk mengatasi kendala retribusi daerah di Kabupaten Gorontalo, berdasarkan hasil wawancara ditemukan 3 (tiga) tema utama terdiri dari kegiatan intensifikasi, kegiatan eksensifikasi, dan pemberian insentif. 
Berdasarkan analisis data dan tema yang ditemukan dari hasil wawancara, studi dokumentasi dan observasi tentang potensi penerimaan retribusi serta upaya yang dilakukan untuk meningkatkan penerimaan retribusi daerah di Kabupaten Gorontalo, analisanya diuraikan sebagai berikut :

\section{Potensi Penerimaan Retribusi Daerah di Kabupaten Gorontalo}

Sebagai implementasi dari UU No. 28 tahun 2009, Pemerintah Kabupaten Gorontalo menerbitkan Peraturan Daerah (Perda) tentang retribusi daerah, yaitu Perda Nomor 1 tahun 2012 tentang retribusi Jasa Umum, Perda Nomor 2 tahun 2012 tentang Retribusi Jasa Usaha dan Perda Nomor 3 tahun 2012 Tentang Retribusi Perizinan Tertentu. Berdasarkan hasil penelitian dan setelah dilakukan studi dokumentasi dan observasi, bisa disimpulkan bahwa pemungutan retribusi daerah di Kabupaten Gorontalo sudah berjalan sesuai dengan regulasi yang berlaku. Regulasi adalah peraturan yang menjadi dasar pelaksanaan suatu kegiatan. Johan den Hertog (1999:223) mendefinisikan regulasi sebagai penerapan instrumen hukum untuk melaksanakan tujuan kebijakan sosial-ekonomi. Karakteristik instrumen hukum adalah bahwa individu atau organisasi dapat dipaksa oleh pemerintah untuk memenuhi perilaku yang ditetapkan dengan ancaman hukuman sanksi. Perubahan dalam regulasi yang berkaitan dengan pemungutan retribusi daerah membawa pengaruh yang positif terhadap penerimaan daerah.

Terkait dengan hasil wawancara bisa disimpulkan bahwa penetapan target penerimaan retribusi daerah di Kabupaten Gorontalo selang tahun 2011 sampai dengan 2016 belum didasarkan pada penilaian potensi rillnya. Pekei (2016:7), menyatakan bahwa pemerintah selalu menargetkan penerimaan daerah hanya berdasarkan Incremental potential yang menyebabkan realisasi penerimaan tampak selalu diatas target. Para pakar anggaran berpendapat bahwa incrementalism ini sudah tidak sesuai lagi untuk digunakan, terlebih pada tingkat pemerintahan daerah dengan tingkat desentralisasi yang lebih besar (Mardiasmo, 2007:109). Tuntutan akan kemandirian keuangan daerah yang sangat dipengaruhi oleh kemampuan daerah dalam meningkatkan PAD. Pemerintah Kabupaten Gorontalo dalam mengambil keputusan terkait dengan penetapan target penerimaan retribusi sebaiknya melakukan analisis potensi untuk mengukur potensi penerimaan setiap jenis retribusi. Harun (2004:1) menyatakan bahwa salah satu upaya yang dilakukan untuk meningkatkan PAD yaitu dengan menetapkan target PAD secara rasional. Hal ini sejalan dengan Teori rasional komprehensif yang menyatakan pengambilan keputusan mengandung arti pemilihan alternatif terbaik dari sejumlah alternatif yang tersedia. Hasil dari proses pengambilan keputusan berdasarkan teori rasional komprehensif merupakan suatu keputusan yang dapat mencapai tujuan yang paling efektif.

Etzioni dalam Parsons (2006:300) menyebut model mixed scanning sebagai pendekatan yang rasionalistis untuk pembuatan keputusan memerlukan sumber daya yang lebih besar ketimbang yang bisa dipakai oleh pembuat keputusan. Strategi inkremental yang mempertimbangkan keterbatasan kemampuan aktor, telah menciptakan keputusan yang mengabaikan inovasi masyarakat. Model mixed scanning ini membuat dualisme tersebut menjadi eksplisit dengan mengkombinasikan (a) proses pembuatan kebijakan yang fundamental dan high-order, yang menentukan arah dasar dan (b) proses inkremental yang disiapkan untuk keputusan fundamental dan untuk melaksanakannya setelah keputusan itu tercapai. Sesuai hasil penelitian ditemukan bahwa SKPD pengelola retribusi dalam menetapkan target penerimaan pada Pemerintah Kabupaten Gorontalo belum menerapkan teori rasional komprehensif. Penetapan target penerimaan retribusi masih mengggunakan teori inkremental. Sesuai analisis hasil penelitian penetapan target retribusi dapat dilakukan dengan menggunakan teori mixed scanning yang merupakan gabungan dari teori teori rasional komprehensif dan teori inkremental.

Berdasarkan hasil penelitan dapat disimpulkan bahwa tanggung jawab SKPD selaku pengelola retribusi adalah menentukan tarif retribusi daerah. Tarif tersebut diperoleh melalui kajian-kajian yang kemudian akan diusulkan ke Badan Keuangan selaku koordinator pendapatan . Untuk tarif yang berlaku saat ini sudah sesuai dengan kondisi perekonomian di Kabupaten Gorontalo serta prinsip dan sasaran penetapan tarif sesuai dengan UU No. 28 tahun 2009. Prinsip dan sasaran penetapan tarif sesuai UU No. 28 Tahun 2009 untuk masing-masing golongan retribusi. Penyesuaian tarif dalam UU nomor 28 tahun 2009 pasal 155 disebutkan pada ayat (1). Tarif Retribusi ditinjau kembali paling lama 3 (tiga) tahun sekali, (2) Peninjauan tarif Retribusi sebagaimana dimaksud pada ayat (1) dilakukan dengan memperhatikan indeks harga dan perkembangan perekonomian, (3) Penetapan tarif Retribusi sebagaimana dimaksud pada ayat (2) ditetapkan dengan Peraturan Kepala Daerah.

Dari hasil penelitian disimpulkan bahwa mekanisme sistim dan prosedur penerimaan retribusi daerah di Kabupaten Gorontalo belum sepenuhnya memenuhi persyaratan sebagaimana tertuang 
dalam Permendagri Nomor 13 tahun 2006 yang telah dirubah untuk terakhir kalinya dengan Permendagri nomor 21 tahun 2011, karena berdasarkan observasi yang dilakukan selama penelitian, ditemukan bahwa SKPD pengelola retribusi daerah belum membuat standar operasional prosedur (SOP) atas pelaksanaan kegiatan pemungutan retribusi daerah yang dikelolanya. Suwanda dan Dailibas (2016:155) menyebutkan bahwa tujuan dibuatnya SOP tersebut yaitu untuk memberikan pedoman bagi seluruh kementerian, lembaga, atau pemerintah daerah dalam mengidentifikasi, merumuskan, menyusun, mengembangkan, memantau, dan mengevaluasi administrasinya sehingga sesuai dengan tugas dan fungsi masing-masing. SOP pengelolaan keuangan daerah sebagaimana terdapat dalam bagan Alir Permendagri No. 13 tahun 2006 yang telah dirubah untuk dengan Permendagri nomor 59 tahun 2007 dan kemudia dirubah dengan Permendagri nomor 21 tahun 2011, menjelaskan bahwa pelaksanaan pendapatan daerah dilakukan oleh: 1) Bendahara Penerimaan; 2) Bendahara Penerimaan Pembantu; 3) Bank Kas Daerah; 4) Bank Lainnya. Penatausahaan penerimaan retribusi daerah dimasing-masing SKPD dapat dilakukan oleh Bendahara penerimaan atau bendaharawan pembantu yang diangkat dengan Surat Keputusan Bupati. Dokumen sumber digunakan sebagai bukti yang sah dalam penatausahaan penerimaan retribusi daerah antara lain surat tanda setoran (STS), surat ketetapan retribusi (SKR) dan surat tanda bukti pembayaran /atau bukti lain yang sah.

Penerimaan retribusi daerah di Kabupaten Gorontalo sesuai dengan hasil penelitian, masih potensial untuk dikembangkan. Sebagaimana hasil analisis potensi retribusi daerah di Kabupaten Gorontalo. Analisis potensi bermanfaat bagi manajemen pemerintah daerah maupun calon investor untuk memberikan pertimbangan tentang potensi penerimaan yang masih dapat digali dan potensi keuntungan berinvestasi. Analisis potensi PAD dilakukan untuk mengetahui jenis pajak daerah dan retribusi daerah tertentu apakah masuk dalam kategori potensial, prima, berkembang ataukah terbelakang (Mahmudi, 2015:147). Analisis potensi penerimaan retribusi daerah dapat ditentukan dengan melihat rasio pertumbuhan dan rasio proporsi dari masing-masing jenis retribusi. Penentuan ratio pertumbuhan dilakukan dengan membandingan pertumbuhan jenis retribusi tertentu dengan pertumbuhan total retribusi daerah. Rasio pertumbuhan dan rasio proporsi retribusi daerah Kabupaten Gorontalo tahun 2011 sampai dengan 2016 dapat dilihat pada Tabel 1 berikut :

Tabel 1

Rasio Pertumbuhan Retribusi Daerah Kabupaten Gorontalo

Periode Tahun 2011-2016

\begin{tabular}{|c|c|c|c|c|c|c|c|}
\hline No & Jenis Retribusi & 2011-2012 & 2012-2013 & 2013-2014 & 2014-2015 & 2015-2016 & Rata-Rata \\
\hline I & Retribusi Jasa Umum & 2.30 & 0.83 & 2.11 & 2.15 & -1.08 & 1.26 \\
\hline 1 & Retribusi Pelayanan Kesehatan & 499.23 & -2.19 & 1.16 & 1.99 & -5.84 & -98.87 \\
\hline 2 & Retribusi Pelayanan Persampahan / & 0.10 & 38.64 & -0.33 & -0.06 & -5.86 & -6.50 \\
\hline 3 & $\begin{array}{l}\text { Retribusi Penggantian Biaya KTP dan } \\
\text { Akte Catatan Sipil }\end{array}$ & 0.11 & -1.35 & 1.81 & 0.00 & 0.00 & -0.12 \\
\hline 4 & Retribusi Parkir Di Tepi Jalan Umum & -0.01 & 4.83 & -0.03 & -0.47 & -0.44 & -0.78 \\
\hline 5 & Retribusi Pelayanan Pasar & 0.00 & 33.76 & -0.24 & 0.06 & -5.95 & -5.53 \\
\hline 6 & Retribusi Pengujian Kendaraan & 0.24 & 9.05 & -0.35 & 0.09 & -17.58 & 1.71 \\
\hline II & Retribusi Jasa Usaha & -0.03 & -4.21 & -3.33 & 0.71 & 2.57 & -0.86 \\
\hline 1 & Retribusi Pemakaian Kekayaan & 10.52 & 4.69 & 4.97 & 2.05 & 1.41 & 4.73 \\
\hline 2 & Retribusi Pasar Grosir/Pertokoan & -14.07 & -0.61 & 0.42 & 1.28 & 2.56 & -2.08 \\
\hline 3 & Retribusi Terminal & 0.23 & -0.65 & 0.01 & -0.47 & -1.84 & -0.54 \\
\hline 4 & Retribusi Tempat Khusus Parkir & -40.64 & -0.44 & -0.14 & -1.40 & 2.05 & -8.11 \\
\hline 5 & Retribusi Rumah Potong Hewan & -8.70 & 6.46 & 0.49 & 6.05 & -5.34 & -0.21 \\
\hline 6 & Retribusi Pejualan Produk Usaha & 0.00 & -3.96 & 5.09 & -3.76 & -5.56 & -1.64 \\
\hline 7 & Retribusi Tempat Rekreasi dan & 0.23 & 0.71 & 0.63 & 0.33 & 2.09 & 0.80 \\
\hline III & Retribusi Perizinan Tertentu & 0.01 & 5.65 & -0.31 & -0.58 & 1.77 & 1.31 \\
\hline 1 & Retribusi Izin Mendirikan Bangunan & 32.30 & 3.43 & -0.32 & 0.47 & 1.68 & 7.51 \\
\hline 2 & Retribusi Izin Gangguan/Keramaian & 40.27 & -0.38 & 3.72 & 1.25 & 1.01 & 9.17 \\
\hline 3 & Retribusi Izin Trayek & -77.85 & -6.57 & 0.30 & -3.88 & 5.19 & -16.56 \\
\hline
\end{tabular}

Sumber Data : Hasil olahan data (2017)

Pada Tabel 1 terlihat bahwa rata-rata rasio pertumbuhan retribusi daerah di Kabupaten Gorontalo yang mengalami kenaikan retribusi jasa umum sebesar $1,26 \%$ dan retribusi perizinan tertentu sebesar $1,31 \%$, sedangkan retribusi jasa usaha rasio pertumbuhannya turun sebesar $0,86 \%$. 
Tabel 2

Rasio Proporsi Retribusi Daerah Kabupaten Gorontalo

Periode Tahun 2011-2016

\begin{tabular}{|c|l|c|c|c|c|c|c|}
\hline No & \multicolumn{1}{|c|}{ Jenis Retribusi } & $\mathbf{2 0 1 1 - 2 0 1 2}$ & $\mathbf{2 0 1 2 - 2 0 1 3}$ & $\mathbf{2 0 1 3 - 2 0 1 4}$ & $\mathbf{2 0 1 4 - 2 0 1 5}$ & $\mathbf{2 0 1 5 - 2 0 1 6}$ & Rata-Rata \\
\hline I & Retribusi Jasa Umum & $\mathbf{2 . 0 8}$ & $\mathbf{2 . 0 7}$ & $\mathbf{1 . 3 4}$ & $\mathbf{1 . 0 6}$ & $\mathbf{5 . 0 0}$ & $\mathbf{2 . 3 1}$ \\
\hline 1 & Retribusi Pelayanan Kesehatan & 6.15 & 5.06 & 4.21 & 1.84 & 1.83 & $\mathbf{3 . 8 2}$ \\
\hline 2 & $\begin{array}{l}\text { Retribusi Pelayanan Persampahan / } \\
\text { Kebersihan }\end{array}$ & 0.03 & 0.04 & 0.10 & 0.13 & 0.13 & $\mathbf{0 . 0 8}$ \\
\hline 3 & Retribusi Parkir Di Tepi Jalan Umum & 0.07 & 0.06 & 0.13 & 0.20 & 0.17 & $\mathbf{0 . 1 3}$ \\
\hline 4 & Retribusi Pelayanan Pasar & 0.51 & 0.72 & 1.65 & 2.07 & 2.06 & $\mathbf{1 . 4 0}$ \\
\hline 5 & $\begin{array}{l}\text { Retribusi Pengujian Kendaraan } \\
\text { Bermotor }\end{array}$ & 0.21 & 0.22 & 0.52 & 0.64 & 0.81 & $\mathbf{0 . 4 8}$ \\
\hline II & Retribusi Jasa Usaha & $\mathbf{0 . 4 0}$ & $\mathbf{0 . 3 5}$ & $\mathbf{0 . 8 4}$ & $\mathbf{0 . 8 8}$ & $\mathbf{0 . 9 2}$ & $\mathbf{0 . 6 8}$ \\
\hline 1 & $\begin{array}{l}\text { Retribusi Pemakaian Kekayaan } \\
\text { Daerah }\end{array}$ & 1.78 & 0.94 & 2.59 & 2.26 & 2.31 & $\mathbf{1 . 9 8}$ \\
\hline 2 & Retribusi Pasar Grosir/Pertokoan & 2.24 & 2.30 & 1.71 & 1.65 & 1.81 & $\mathbf{1 . 9 4}$ \\
\hline 3 & Retribusi Terminal & 1.83 & 1.88 & 1.06 & 1.25 & 1.03 & $\mathbf{1 . 4 1}$ \\
\hline 4 & Retribusi Tempat Khusus Parkir & 0.10 & 0.10 & 0.05 & 0.07 & 0.07 & $\mathbf{0 . 0 8}$ \\
\hline 5 & Retribusi Rumah Potong Hewan & 0.11 & 0.04 & 0.03 & 0.01 & 0.01 & $\mathbf{0 . 0 4}$ \\
\hline 6 & $\begin{array}{l}\text { Retribusi Pejualan Produk Usaha } \\
\text { Daerah }\end{array}$ & 0.04 & 0.05 & 0.15 & 0.24 & 0.15 & $\mathbf{0 . 1 3}$ \\
\hline 7 & $\begin{array}{l}\text { Retribusi Tempat Rekreasi dan } \\
\text { Olahraga }\end{array}$ & 1.87 & 1.68 & 1.40 & 1.52 & 1.62 & $\mathbf{1 . 6 2}$ \\
\hline III & Retribusi Perizinan Tertentu & $\mathbf{0 . 5 2}$ & $\mathbf{0 . 5 8}$ & $\mathbf{0 . 8 2}$ & $\mathbf{1 . 0 6}$ & $\mathbf{1 . 0 8}$ & $\mathbf{0 . 8 1}$ \\
\hline 1 & Retribusi Izin Mendirikan Bangunan & 1.60 & 2.46 & 1.86 & 1.42 & 1.10 & $\mathbf{1 . 6 9}$ \\
\hline 2 & Retribusi Izin Gangguan/Keramaian & 3.09 & 3.12 & 3.09 & 2.52 & 1.89 & $\mathbf{2 . 7 4}$ \\
\hline 3 & Retribusi Izin Trayek & 0.19 & 0.03 & 0.02 & 0.01 & 0.01 & $\mathbf{0 . 0 5}$ \\
\hline
\end{tabular}

Pada Tabel 2 dapat dilihat rasio proporsi retribusi daerah di Kabupaten Gorontalo yang tertinggi adalah retribusi jasa umum yaitu sebesar $2,31 \%$, retribusi perizinan tertentu sebesar $0,81 \%$, sedangkan retribusi jasa usaha hanya sebesar $0,68 \%$. Berdasarkan rasio proporsi dan rasio pertumbuhan tersebut pada Tabel 1 dan Tabel 2, bisa di buat matrik penilaian potensi penerimaan retribusi daerah di Kabupaten Gorontalo tahun 2011 sampai dengan 2016 dan hasil analisa datanya pada Tabel 3 berikut ini :

Tabel 3

Klasifikasi Potensi Retribusi Daerah Kabupaten Gorontalo Periode Tahun 2011-2016

\begin{tabular}{|c|c|c|c|c|c|}
\hline No & Jenis Retribusi & $\begin{array}{c}\% \\
\text { Pertumbuhan }\end{array}$ & \begin{tabular}{|c|} 
Rasio \\
Pertumbuhan
\end{tabular} & $\begin{array}{c}\text { Rasio } \\
\text { Proporsi }\end{array}$ & Kl asifi kasi \\
\hline $\mathbf{I}$ & Retribusi Jasa Umum & 20.62 & \begin{tabular}{l|l}
1.05 & \\
\end{tabular} & 1.92 & Prima \\
\hline 1 & Retribusi Pelayanan Kesehatan & 18733.31 & -82.39 & 3.18 & Potensial \\
\hline 2 & Retribusi Pelayanan Persampahan / & 25.65 & -5.42 & 0.07 & Terbel akang \\
\hline 3 & Retribusi Parkir Di Tepi Jalan Umum & 8.13 & -0.65 & 0.10 & Terbel akang \\
\hline 4 & Retribusi Pelayanan Pasar & -4.96 & -4.61 & 1.17 & Potensial \\
\hline 5 & Retribusi Pengujian Kendaraan & 24.92 & 1.42 & 0.40 & Berkembang \\
\hline 6 & Retribusi Menara Telekomunikasi & 0.00 & 1.77 & 0.24 & Berkembang \\
\hline II & Retribusi Jasa Usaha & 12.66 & -0.72 & $\mathbf{0 . 5 7}$ & Terbel akang \\
\hline 1 & $\begin{array}{l}\text { Retribusi Pemakaian Kekayaan } \\
\text { Daerah }\end{array}$ & 62.35 & 3.94 & 1.65 & Prima \\
\hline 2 & Retribusi Pasar Grosir/Pertokoan & 16.06 & -1.73 & 1.62 & Potensial \\
\hline 3 & Retribusi Terminal & -2.28 & -0.45 & 1.18 & Potensial \\
\hline 4 & Retribusi Tempat Khusus Parkir & 26.14 & -6.76 & 0.07 & Terbel akang \\
\hline 5 & Retribusi Rumah Potong Hewan & -20.34 & -0.17 & 0.03 & Terbel akang \\
\hline 6 & $\begin{array}{l}\text { Retribusi Pejualan Produk Usaha } \\
\text { Daerah }\end{array}$ & 90.60 & -1.36 & O.11 & Terbel akang \\
\hline 7 & $\begin{array}{l}\text { Retribusi Tempat Rekreasi dan } \\
\text { Olahraga }\end{array}$ & 13.51 & 0.67 & 1.35 & Potensial \\
\hline III & Retribusi Perizinan Tertentu & 6.97 & 1.09 & 0.68 & Berkembang \\
\hline 1 & Retribusi Izin Mendirikan Bangunan & 16.45 & 6.26 & 1.41 & Prima \\
\hline 2 & Retribusi Izin Gangguan/Keramaian & 14.74 & 7.64 & 2.29 & Prima \\
\hline 3 & Retribusi Izin Trayek & -57.25 & -13.80 & 0.04 & Terbel akang \\
\hline
\end{tabular}

Pada Tabel 3 dapat dilihat bahwa secara umum retribusi jasa umum merupakan retribusi yang penerimaannya sangat potensial (Prima), karena rasio pertumbuhan dan rasio proporsinya lebih dari satu sehingga sangat layak untuk diteruskan pemungutannya. Retribusi jasa usaha merupakan retribusi 
yang terbelakang karena rasio pertumbuhan dan rasio proporsinya kurang dari satu sedangkan retribusi perizinan tertentu masuk dalam retribusi yang berkembang karena rasio pertumbuhannya lebih dari satu sedangkan rasio proporsinya kurang dari satu.

Analisis perhitungan potensi mutlak diperlukan dalam analisis menetapkan target rasional. Dengan potensi yang ada, setelah dibandingkan perkiraan penerimaan untuk masa yang akan datang, maka akan kita dapatkan besarnya potensi yang terpendam, sehingga akan dapat diperkirakan rencana tindakan apa yang akan kita lakukan untuk menggali potensi terpendam tersebut untuk menentukan berapa besarnya rencana penerimaan yang akan datang (Harun, 2003:1). Selain dengan cara menghitung penerimaan jenis retribusi dan penerimaan total retribusi, rasio proporsi dan rasio pertumbuhan, proyeksi potensi penerimaan dan penentuan tarif retribusi juga dapat diketahui dari beberapa hal, yaitu: 1) Kebutuhan / permintaan masyarakat akan jasa pelayanan tersebut; 2) Besarnya Tarif retribusi yang ditetapkan; 3) Sarana prasarana yang mendukung pelayanan tersebut; 4) Tingkat/kualitas pelayanan yang diberikan (Kementerian Keuangan RI, 2014:103).

\section{Kendala-Kendala Penerimaan Retribusi Daerah di Kabupaten Gorontalo}

Hasil wawancara menunjukkan $57,89 \%$ dari informan menyatakan bahwa kendala dalam peningkatan penerimaan retribusi daerah di Kabupaten Gorontalo adalah sumber daya manusia (SDM) baik secara kuantitas maupun kualitasnya masih kurang. SDM mempunyai peran sangat menentukan hidup matinya organisasi perusahaan. Apabila SDM dalam perusahaan bermoral baik, disiplin, loyal, dan produktif maka organisasi/ perusahaan dapat berkembang baik. Apabila SDM bersifat statis, bermoral rendah, senang korupsi, kolusi dan nepotisme akan menghancurkan organisasi/ perusahaan (Sedarmayanti, 2016:12). Di Kabupaten Gorontalo SDM yang ada secara kuantitas, masih dibutuhkan penambahan jumlah SDM pengelola retribusi daerah dan peningkatan kualitas SDM juga diperlukan. Sedangkan peningkatan kualitas SDM dalam hal ini adalah kompetensi pengelola retribusi daerah juga perlu ditingkatkan. Kompetensi menurut Sedarmayanti (2010:21) adalah segala hal pengetahuan, keahlian, kemampuan dan karateristik lain yang menyebabkan seseorang pemegang suatu jabatan mampu melaksanakan peran dan tanggung jawabnya dan memberikan kontribusi bagi pemenuhan kebutuhan organisasi sesuai tingkat jabatan yang dipegangnya dan diestimasikan bahwa kompetensi yang dibutuhkan agar organisasi dapat survive dalam menghadapi tantangan dan perubahan dimasa depan.

Berdasarkan hasil wawancara 52,63\% informan dari SKPD pengelola retribusi menyatakan kendala yang dihadapi berupa fasilitas yang belum memadai. Dari hasil analisis data disimpulkan bahwa di Kabupaten Gorontalo sebagian besar SKPD pengelola retribusi menyatakan bahwa fasilitasfasilitas yang digunakan dalam pelayanan sudah tidak memadai karena sudah banyak yang rusak dan tidak ada anggaran untuk melakukan pemeliharaan ataupun peremajaan fasilitas-fasilitas tersebut, sehingga dalam memberikan pelayanan kepada wajib retribusi tidak maksimal. Menurut Kotler (2009: 45), fasilitas merupakan segala sesuatu yang bersifat peralatan fisik yang disediakan oleh pihak penjual jasa untuk mendukung kenyamanan konsumen. Fasilitas erat kaitannya dengan kualitas pelayanan publik. Salah satu prinsip dari penyelenggaraan pelayanan publik adalah kelengkapan sarana dan prasarana : tersedianya sarana dan prasarana kerja, peralatan kerja dan pendukung lainnya yang memadai termasuk penyediaan sarana teknologi telekomunikasi dan informasi (Surjadi, 2009:66).

Berdasarkan hasil penelitian ditemukan bahwa pengawasan pemungutan retribusi di Kabupaten Gorontalo belum efektif pelaksanaannya, hasil wawancara menunjukan 47,37\% informan menyatakan bahwa kendala dalam peningkatan penerimaan retribusi daerah di Kabupaten Gorontalo adalah kurangnya pengawasan. Hal ini mengakibatkan masih ada potensi penerimaan yang hilang. Pengawasan atas pelaksanaan pemungutan retribusi seharusnya dilakukan oleh SKPD pengelola retribusi daerah itu sendiri dan Badan Keuangan selaku koordinator pegelolaan pendapatan daerah dan lebih utama lagi pengawasan oleh Inspektorat. Pengawasan secara menyeluruh mulai dari proses pemungutannya sampai dengan pelaporannya harus didukung dengan bukti-bukti transaksi yang valid sehingga dapat dipertanggungjawabkan. Pengawasan (controlling) atau yang dikenal juga dengan evaluating atau correcting merupakan salah satu fungsi manajemen yang bertujuan untuk memastikan tujuan organisasi bisa dicapai. Dalam definisi yang lebih luas yang disampaikan oleh Siagian (2007:125), pengawasan adalah proses pengamatan dari seluruh kegiatan organisasi untuk menjamin agar supaya semua pekerjaan yang sedang dilakukan berjalan sesuai dengan rencana yang telah ditentukan sebelumnya. 
Berdasarkan hasil analisis data di simpulkan bahwa permasalahan lain yang menjadi kendala peningkatan penerimaan retribusi daerah di Kabupaten Gorontalo yakni, belum diterapkannya aturan pemberian sanksi keterlambatan pembayaran retribusi secara menyeluruh sesuai dengan ketentuan yang berlaku, 36,48\% informan menyatakan hal tersebut. Hal ini mengakibatkan wajib retribusi yang telah menerima atau memanfaatkan layanan/jasa yang disediakan pemerintah daerah tidak menyadari akan kewajiban retribusinya atau dengan kata lain tidak ada efek jera. Hal ini tentu saja tidak sejalan dengan UU No. 28 tahun 2009, dijelaskan bahwa sanksi administratif diatur dengan peraturan kepala daerah. Berdasarkan Peraturan Daerah Kabupaten Gorontalo diketahui bahwa dalam hal wajib retribusi tertentu tidak membayar tepat pada waktunya atau kurang membayar, dikenakan sanksi administratif berupa bunga sebesar $2 \%$ setiap bulan dari retribusi terutang yang tidak atau kurang dibayar dan ditagih dengan menggunakan surat tagihan retribusi daerah (STRD) yang diawali dengan pemberian surat teguran. Sanksi menurut Nugroho (2006) adalah hukuman negatif kepada orang yang melanggar peraturan, dan denda adalah hukuman dengan cara membayar uang karena melanggar peraturan dan hukum yang berlaku, sehingga dapat dikatakan bahwa sanksi denda adalah hukuman negatif kepada orang yang melanggar peraturan dengan cara membayar uang. Pemberian sanksi administratif diharapkan bisa meningkatkan kesadaran wajib retribusi sehingga peningkatan penerimaan retribusi daerah bisa berjalan sesuai dengan yang direncanakan.

Selain itu terdapat juga kendala yang terkait dengan tingkat kesadaran wajib retribusi, 26,32\% dari informan menyatakan hal tersebut. Hal ini ditandai dengan masih adanya tunggakan-tunggakan retribusi. Berdasarkan analisis data ditemukan bahwa masih terdapat wajib retribusi yang menunggak hal ini menggambarkan bahwa kesadaran masyarakat sebagai wajib retribusi masih kurang walaupun mereka sudah menikmati pelayanan/jasa yang disediakan oleh pemerintah. Menurut Kamus Bahasa Indonesia kesadaran sosial adalah kesadaran seseorang secara penuh akan hak dan kewajibannya sebagai anggota masyarakat. Untuk meningkatkan kesadaran wajib retribusi agar mereka patuh melaksanakan kewajiban retribusinya, maka perlu diterapkan peraturan tentang pemberian sanksi sebagaimana tercantum dalam UU No. 28 tahun 2009. Sehubungan dengan kesadaran wajib retribusi, jika diasumsikan bahwa pemungutan retribusi sama dengan pemungutan pajak maka kesadaran wajib retribusi berpengaruh terhadap tingkat kepatuhan wajib retribusi, sebagaimana hasil penelitian (Nugroho, 2006).

Kendala lainnya dalam upaya peningkatan retribusi daerah di Kabupaten Gorontalo adalah kurangnya sosialisasi ke masyarakat $15,79 \%$ informan menyatakan hal tersebut. Sosialisasi adalah upaya untuk memperkenalkan sesuatu kepada orang lain. Sosialisasi tentang pemungutan retribusi daerah diperlukan untuk memperkenalkan kepada masyarakat/wajib retribusi tentang pemungutan retribusi. Hal ini bertujuan agar masyarakat mengetahui jenis-jenis layanan publik yang disediakan oleh pemerintah daerah, dan kewajiban untuk melakukan pembayaran jika mereka memanfaatkan atau menggunakan layanan tersebut. Sosialisasi juga diperlukan untuk meningkatkan kesadaran wajib retribusi. Shaw (1979) menyatakan bahwa jika media memberi tekanan pada suatu peristiwa, maka media itu akan mempengaruhi khalayak untuk menganggapnya penting. Jadi apa yang dianggap penting media, maka penting juga bagi masyarakat. Dalam hal ini media diasumsikan memiliki efek yang sangat kuat, terutama karena asumsi ini berkaitan dengan proses belajar bukan dengan perubahan sikap dan pendapat.

Dari hasil penelitian disimpulkan bahwa dalam pengelolaan retribusi daerah di Kabupaten Gorontalo terdapat beberapa jenis retribusi daerah yang membutuhkan koordinasi dengan Institusi Kepolisian atau dengan Instansi terkait pemungutan retribusi yang dilakukan. Seperti halnya untuk retribusi yang dikelola oleh Dinas Perhubungan yakni retribusi parkir tepi jalan umum, retribusi pengujian kendaraan bermotor dan retribusi izin trayek. Untuk memaksimalkan pemungutan retribusiretribusi tersebut Dinas Perhubungan harus berkoordinasi dengan Institusi Kepolisian untuk meningkatkan pengawasan. Koordinasi antara SKPD pengelola retribusi daerah juga diperlukan seperti untuk retribusi pasar dan retribusi pelayanan persampahan untuk kebersihan di lingkungan pasar, harus ada batasan yang jelas tentang pemungutan retribusi terkait pengelolaan persampahan di lingkungan pasar, karena selama ini pengelola pasar memungut retribusi kebersihan yang sama dengan Dinas Lingkungan Hidup dan SDA sehingga membuka peluang untuk terjadinya pungutan ganda dan berpotensi untuk menimbulkan konflik mengingat upaya masing-masing SKPD untuk memenuhi target yang diberikan. Dalam kamus besar Indonesia, koordinasi diartikan sebagai perihal mengatur suatu organisasi atau kegiatan sehingga peraturan dan tindakan yang akan dilaksanakan tidak saling bertentangan atau simpang siur. Indrawijaya (2010:123) menyatakan bahwa hal yang penting diperhatikan adalah bahwa dalam pandangan prilaku organisasi, koordinasi bukan hanya merupakan 
penentuan dan pelaksanaan aturan permainan yang sudah ditetapkan secara formal, tetapi merupakan pula sesuatu yang dapat menimbulkan konflik dan juga dapat digunakan untuk menangani suatu konflik.

\section{Upaya-Upaya untuk Mengatasi Kendala Penerimaan Retribusi Daerah di Kabupaten Gorontalo.}

Upaya Pemerintah Kabupaten Gorontalo untuk mengatasi kendala-kendala dalam meningkatkan penerimaan retribusi daerah yaitu dengan melakukan kegiatan intensifikasi dan ekstensifikasi. Kegiatan Intensifikasi yang dilakukan adalah :

1. Peningkatan kualitas SDM pengelola retribusi daerah, hal ini dimaksudkan untuk pemenuhan kompetensi pegawai pengelola retribusi daerah. Berdasarkan hasil wawancara masih ditemukan bahwa petugas pengelola retribusi yang belum memahami betul tugas dan fungsinya. Menurut Edison et al (2016:10) manajemen sumber daya manusia adalah proses mengelola, memotivasi dan membangun sumber daya manusia untuk dapat menunjang aktivitas organisasi secara efektif dan efisien sesuai dengan tujuan strategis organisasi, salah satunya melalui perencanaan dan pengembangan kompetensi pegawai serta mempersiapkan perencanaan karir yang jelas dan sesuai dengan tujuan organisasi. Pengembangan SDM melalui peningkatan kompetensi SDM telah dilakukan oleh Pemerintah Kabupaten Gorontalo yaitu melalui pelaksanaan diklat atau bimtek terkait pengelolaan keuangan daerah setiap tahunnya.

2. Perbaikan kualitas layanan publik yang dilakukan untuk memperbaiki fasilitas atau sarana prasarana penunjang pelaksanaan pelayanan publik yang dipungut retribusinya tersebut. Dalam hal ini diperlukan kebijakan di bidang penganggaran yang walaupun belum bisa tercover seluruhnya namun tetap masuk dalam perencanaan pengganggaran di SKPD pengelola retribusi daerah.

3. Menggiatkan sosialisasi kepada masyarakat tentang pelayanan yang disediakan oleh pemerintah dan kewajiban yang harus dilaksanakan jika mereka menikmati layanan tersebut. Upaya menggiatkan sosialisasi ini juga dimaksudkan untuk menimbulkan kesadaran masyarakat dalam memenuhi kewajiban retribusinya.

4. Meningkatkan koordinasi baik antara Badan Keuangan sebagai koordinator dalam pelaksanaan kegiatan intensifikasi dengan SKPD pengelola retribusi untuk meningkatkan penerimaan retribusi daerah.

5. Meningkatkan pengawasan terhadap pemungutan retribusi di Kabupaten Gorontalo terhadap pencapaian target penerimaan yang dilakukan oleh Badan Keuangan selaku koordinator pengelolaan pendapatan daerah dan Inspektorat selaku unsur pengawasan di daerah.

6. Melakukan penerapan sanksi, penerapan sanksi ini belum diterapkan secara menyeluruh namun Pemerintah Kabupaten Gorontalo berupaya untuk memenuhi amanat UU No. 28 tahun 2009 terkait penerapan sanksi retribusi dan hal ini telah ditegaskan oleh Sekretaris Daerah berdasarkan hasil wawancara, walaupun masih terdapat pertimbangan-pertimbangan dalam pelaksanaannya.

Ekalia Yuniza (2016) mendefinisikan intensifikasi sebagai suatu usaha untuk meningkatkan jumlah penerimaan retribusi daerah dengan tidak merubah sumber penerimaan baru atau dengan kata lain bagaimana cara mengelola yang telah ada menjadi sumber penerimaan daerah yang baik dengan mengidentifikasi pemungutan retribusi daerah dan mengefisiensikan cara pemungutannya pada subjek dan objek yang sudah dikenakan sebelumnya. Cara intensifikasi adalah melakukan pemungutan secara efektif dan efisien pada objek dan subjek pajak daerah yang sudah ada misalnya melakukan perhitungan potensi, penyuluhan, peningkatan pengawasan dan pelayanan (Kementerian Keuangan RI, Dirjen Perimbangan, 2014:92). Untuk mendukung upaya peningkatan retribusi daerah melalui kegiatan instensifikasi Pemerintah Kabupaten Gorontalo juga telah melakukan penyesuaian tarif dengan mengeluarkan Peraturan Bupati Nomor 1 tahun 2017 tentang retribusi jasa umum, Peraturan Bupati Nomor 2 tentang retribusi jasa usaha dan Peraturan Bupati Nomor 3 tentang retribusi perizinan tertentu.

Kegiatan Ekstensifikasi yang dilakukan adalah :

1. Melakukan pendataan wajib retribusi untuk menjaring wajib retribusi baru

2. Menggali potensi penerimaan dari sumber-sumber retribusi yang baru untuk jenis retribusi sesuai dengan ketentuan UU No. 28 Tahun 2009. Seperti di tahun 2017 ini terdapat tiga jenis retribusi dengan sumber penerimaan yang baru yaitu retribusi pemanfaatan kekayaan daerah pada Dinas Pertanian yaitu alat-alat mesin pertanian (Alsintan) yang disewakan kepada para petani. Kemudian 
ada pembangunan terminal Telaga yang diharapkan bisa memberikan kontribusi terhadap peningkatan penerimaan retribusi terminal yang ada di Dinas Perhubungan. Dan dari hasil observasi yang dilakukan di Dinas Perindustrian dan Perdagangan terdapat jenis retribusi baru yakni retribusi tera ulang.

Ekstensifikasi penerimaan retribusi daerah yaitu usaha untuk meningkatkan penerimaan retribusi daerah dengan cara memperluas dan menambah sumber-sumber penerimaan baru serta mengaktifkan, mengembangkan, menggali sumber-sumber penerimaan yang ada (Ekalia Yuniza, 2016). Cara ekstensifikasi adalah melakukan usaha-usaha untuk menjaring wajib pajak baru melalui pendataan dan pendaftaran atau menggali pajak baru (Kementerian Keuangan RI, Dirjen Perimbangan, 2014:92).

Alternatif kebijakan atau upaya yang dapat diambil atau diterapkan dalam usaha meningkatkan setiap jenis klasifikasi sesuai dengan analisis potensi penerimaan retribusi akan berbeda-beda. Jika jenis pajak/retribusi daerah termasuk prima, maka kebijaksanaan yang telah diterapkan pada tahuntahun sebelumnya dapat tetap digunakan dengan mempertahankan tingkat pertumbuhan dan kontribusinya. Jika jenis pajak termasuk penerimaan yang potensial, maka upaya yang perlu dilakukan adalah dengan mengintensifkan pemungutan dari sumber penerimaan yang ada sehingga terjadi pertumbuhan penerimaan. Untuk pajak/retribusi daerah dengan klasifikasi berkembang, upaya peningkatan yang dilakukan adalah dengan menggali sumber-sumber baru dengan tingkat pertumbuhan seperti pada tahun-tahun sebelumnya. Jika pajak/retribusi daerah dalam klasifikasi terbelakang, maka upaya peningkatannya dilakukan dengan menggali sumber-sumber penerimaan baru dan meningkatkan penerimaan dari tahun sebelumnya dari sumber penerimaan yang ada (Kementerian Keuangan RI, Dirjen Perimbangan, 2014:92).

Selain upaya intensifikasi dan ekstensifikasi untuk meningkatkan penerimaan retribusi daerah di Kabupaten Gorontalo, pemerintah daerah memberikan insentif kepada SKPD yang melaksanakan pemungutan retribusi daerah atas pencapaian kinerja tertentu. Insentif ini dimaksudkan untuk memberikan motivasi kepada SKPD pengelola agar lebih giat lagi dalam pemungutan retribusinya. Salah satu bentuk penghargaan atas upaya yang dilakukan SKPD pengelola dalam pemungutan retribusi, maka pemerintah daerah memberikan insentif yang dikenal dengan upah pungut. Hal ini sesuai dengan ketentuan dalam UU No. 28 tahun 2009 yang pelaksanaannya diatur dalam Peraturan Pemerintah Nomor 69 tahun 2010 bagi SKPD pengelola retribusi daerah yang mencapai/melampaui target. Edison et al (2016:157) mendefinisikan insentif adalah bentuk kompensasi diluar upah yang diberikan kepada karyawan atas usaha tambahannya dalam membantu perusahaan.

Berdasarkan pembahasan dapat dilihat bahwa upaya untuk meningkatan penerimaan retribusi daerah di Kabupaten Gorontalo sudah dilaksanakan sesuai dengan UU No. 28 tahun 2009, walaupun masih ada beberapa upaya yang belum maksimal dilakukan untuk mengatasi kendala-kendala peningkatan penerimaan retribusi daerah di Kabupaten Gorontalo.

\section{Kesimpulan}

Kesimpulan yang didapat dari hasil analisis potensi penerimaan retribusi daerah di Kabupaten Gorontalo untuk menjawab rumusan masalah yang telah ditetapkan adalah sebagai berikut :

1. Potensi retribusi daerah di Kabupaten Gorontalo adalah sebagai berikut :

a. Retribusi daerah yang potensi penerimaan tergolong dalam klasifikasi prima adalah retribusi pemakaian kekayaan daerah, retribusi izin mendirikan bangunan dan retribusi izin gangguan/keramaian.

b. Retribusi daerah yang potensi penerimaannya tergolong dalam klasifikasi potensial adalah retribusi pelayanan kesehatan, retribusi pelayanan pasar, retribusi pasar grosir/pertokoan, retribusi terminal dan retribusi tempat rekreasi dan olahraga.

c. Retribusi daerah yang potensi penerimaannya tergolong dalam klasifikasi berkembang adalah retribusi pegujian kendaraan bermotor dan retribusi menara telekomunikasi.

d. Retribusi daerah yang potensi penerimaannya tergolong dalam klasifikasi terbelakang adalah retribusi persampahan/kebersihan, retribusi parkir tepi jalan umum, retribusi tempat parkir khusus, retribusi rumah potong hewan, retribusi penjualan produk usaha daerah dan retribusi izin trayek.

2. Kendala-kendala dalam penerimaan retribusi daerah di Kabupaten Gorontalo terdiri dari beberapa hal yaitu, sumber daya manusia (SDM) secara kualitas dan kuantitas masih kurang, fasilitasfasilitas yang kurang memadai, kurangnya pengawasan, penerapan sanksi yang belum maksimal, kurangnya kesadaran wajib retribusi, kurangnya koordinasi dan kurangnya sosialisasi. 
3. Upaya-upaya untuk mengatasi kendala-kendala penerimaan retribusi oleh Pemerintah Kabupaten Gorontalo yakni dengan melakukan kegiatan :

a. Intensifikasi berupa perubahan tarif retribusi, pelaksanaan sosialisasi, peningkatan kualitas SDM melalui pelatihan-pelatihan, meningkatkan pengawasan atas pemungutan retribusi dan meningkatkan kualitas pelayanan dengan melakukan peremajaan fasilitas-fasiltas.

b. Ektensifikasi dengan melakukan pendataan wajib retribusi untuk menjaring wajib retribusi baru dan menggali potensi penerimaan dari sumber-sumber retribusi yang baru untuk jenis retribusi sesuai dengan ketentuan UU No. 28 Tahun 2009.

c. Selain upaya melalui kegiatan intensifikasi dan ekstensifikasi untuk meningkatkan penerimaan retribusi daerah di Kabupaten Gorontalo, pemerintah daerah memberikan insentif kepada SKPD yang melaksanakan pemungutan retribusi daerah atas pencapaian kinerja tertentu yang disebut dengan upah pungut.

\section{Saran}

Penelitian ini merekomendasikan hal-hal sebagai berikut :

1) Pemerintah Kabupaten Gorontalo dalam menetapkan target penerimaan retribusi menggunakan teori mixed scanning, yaitu dengan melakukan pendataan potensi retribusi sebagai bahan kajian sesuai teori rasional komprehensif dan membandingkannya dengan realisasi tahun sebelumnya berdasarkan teori inkremental.

2) Pemerintah Kabupaten Gorontalo perlu menyediakan anggaran pemeliharaan dan peremajaan fasilitas untuk meningkatkan kualitas pelayanan kepada masyarakat.

3) Pemerintah Kabupaten Gorontalo perlu melakukan sosialisasi secara intensif kepada masyarakat tentang layanan publik yang disediakan oleh pemerintah daerah.

4) Pemerintah Kabupaten Gorontalo perlu memberikan pelatihan kepada pengelola retribusi dalam rangka perbaikan kualitas SDM.

5) Inspektorat perlu mengintesifkan pengawasan terhadap pengelolaan retribusi daerah.

6) Memberlakukan reward and punishment untuk pengelola retribusi daerah secara lebih terbuka/transparan.

7) Bagi Akademisi untuk melakukan penelitian lebih lanjut mengenai potensi penerimaan retribusi berdasarkan analisa klasifikasi potensi penerimaan untuk masing-masing jenis retribusi.

8) Bagi peneliti agar dapat mengaplikasikan ilmu yang didapat selama studi terutama berkaitan dengan fokus penelitian yang dilakukan saat kembali bertugas di Pemerintah Daerah Kabupaten Gorontalo.

\section{Daftar Pustaka}

Afrizal, 2016. Metode Penelitian Kualitatif: Sebuah Upaya Mendukung Menggunakan Penelitian Kualitatif dalam Berbagai Disiplin Ilmu. Jakarta: Rajawali Pers

Edison, Anwar dan Komariyah. (2016). Manajemen Sumber Daya Manusia. Alfabeta Bandung

Harun, Hamrolie (2004), Analisis Peningkatan PAD. BPFE Yogyakarta.

Harun, Hamrolie (2003), Menghitung Potensi Pajak dan Retribusi Daerah. BPFE Yogyakarta.

Hertog, den Johan (1999), General Theories Of Regulation, Economic Institute/CLAV. Ultrecht Univercity.

Indrawijaya. Adam Ibrahim, (2010), Teori Prilaku dan Budaya Organisasi, PT Refika Aditama. Bandung.

Kementerian Keuangan Republik Indonesia. Direktorat Jenderal Perimbangan Keuangan. 2014. Modul Pendapatan Daerah Training of Trainer (TOT) PKD.

Kotler, Philip. 2009. Manajemen Pemasaran, Jilid 2, Edisi 13. Alih Bahasa Benyamin Molan. Jakarta: Prehallindo.

Mahmudi (2015), Analisis Laporan Keuangan Pemerintah Daerah : UPP STIM YKPN. Yogyakarta.

Mardiasmo (2007), Otonomi dan Manajemen Keuangan Daerah Yogyakarta : CV Andi Offset, Yogyakarta

Nugroho, Agus (2006). Pengaruh sikap wajib pajak pada pelaksanaan sanksi denda, pelayanan fiskus dan kesadaran perpajakan terhadap kepatuhan wajib pajak. Tesis: Magister Akuntansi Program Pascasarjana Universitas Diponegoro

Parsons, Wayne (2006), Public Policy, Pengantar Teori dan Analisis Kebijakan, Penerbit Kencana Media Grup, Jakarta. 
Pekei Beni (2016), Konsep Dan Analisis Efektivitas Pengelolaan Keuangan Daerah Di Era Otonomi, Penerbit Taushia, Jakarta .

Pemerintah Kabupaten Gorontalo. Perda Nomor 1 Tahun 2012, tentang Retribusi Jasa Umum. Perda Nomor 2 Tahun 2012, tentang Retribusi Jasa Usaha. Perda Nomor 3 Tahun 2012, tentang Retribusi Perizinan Tertentu. Peraturan Bupati Nomor 1 Tahun 2017, tentang Tarif Retribusi Jasa Umum. Perbup Nomor 2 Tahun 2017, tentang Tarif Retribusi Jasa Usaha. Perbup Nomor 3 Tahun 2017, tentang Tarif Retribusi Perizinan Tertentu.

Pemerintah Republik Indonesia, UU No 28 Tahun 2009 tentang Pajak Daerah Dan Retribusi Daerah . Rizka et al ( 2014), Analisis Strategi Peningkatan Pendapatan Pajak Daerah Dan Retribusi Daerah Dalam Rangka Meningkakan Kemampuan Keuangan Daerah Di Kota Banda Aceh. Jurnal Magister Akuntansi Pasca Sarjana Universitas Syiah Kuala Banda Aceh, ISSN No, 23020164 pp 69-69

Sedamaryanti (2010), Reformasi Administrasi Publik, Reformasi Birokrasi, Dan Kepemimpinan Masa Depan (Mewujudkan Pelayanan Prima dan Kepemerintahan yang Baik). PT Refika Aditama Bandung. (2016), Reformasi Birokrasi Dan Manajemen Pegawai Negeri Sipil. PT. Refika Aditama. Bandung

Siagian, P. Sondang (2007), Fungsi-Fungsi Manajerial (Edisi Revisi). Bumi Aksara. Jakarta

Shaw, Eugene F. "Agenda-setting and mass communication theory." Gazette (Leiden, Netherlands) 25.2 (1979): 96-105.

Suwanda Dadang dan Dailibas (2016), Sistem Pengendalian Intern Pemerintah. PPM. Jakarta

Surjadi. H. (2009), Pengembangan Kinerja Pelayanan Publik, Pt. Refika Aditama, Bandung.

Sugiyono. 2015 Memahami Penelitian Kualitatif. ALFABETA,Bandung .

Wahab, Solichin Abdul (2012), Analisis Kebijaksanaan : Dari Formulasi ke Implementasi Kebijaksanaan Negara. Jakarta : Bumi Aksara

Yuniza, Ekalia (2016), Tesis Faktor-Faktor Yang mempengaruhi Penerimaan Retribusi Pelayanan Parkir Tepi Jalan Umum Di Kota Bandar Lampung. Pasca Sarjana Ilmu Ekonomi Universitas Lampung Bandar Lampung 